\title{
THE RHEOLOGICAL PROPERTIES OF ROCKS IN A COMPRESSIONAL DUCTILE SHEAR ZONE, PHYLLITE-QUARTZITE SERIES, PELOPONNESE
}

\author{
P. XYPOLIAS ${ }^{1}$
}

\section{ABSTRACT}

The magnitudes of differential stress, strain rate and viscosity during the formation of an extruding crustalscale shear zone (Phyllite-Quartzite Series, PQS) were estimated providing new insights on the mechanical behavior of the middle continental crust of the External Hellenides during compression. The differential flow stress during ductile deformation of PQS, in the Taygetos and Chelmos tectonic windows, has been analyzed using grain-size piezometer. Quartz tectonites from the Taygetos and Chelmos areas have mean grain sizes of 42 $\mu \mathrm{m}$ and $51 \mu \mathrm{m}$, respectively. Extrapolation of quartzite flow-laws indicates that tectonic extrusion of the PQS occurred at strain rates slightly faster than $10^{-13} \mathrm{~s}^{-1}$. These estimates suggest that the extruding zone had a relatively low-viscosity of the order of $10^{19}$ to $10^{20} \mathrm{~Pa} \cdot \mathrm{s}$. Finally, the combination of the obtained strain rate values with published quantitative analyses for the deformation path in the PQS implies that during the initial stage of the tectonic extrusion process the displacement rates parallel to the Taygetos-Parnon and Chelmos Thrusts, were $\sim 6 \mathrm{~mm} /$ year and $3 \mathrm{~mm} /$ year, respectively.

KEY WORDS: Quartzites; rheology; ductile shear-zones; Phyllite-Quartzite Series; Peloponnese.

\section{INTRODUCTION}

Although considerable progress has been made by numerous geologists toward the understanding of the geometrical evolution of intraplate thrust faults and the kinematics of the associated ductile shear zones, the magnitudes of several rheological parameters, such as differential stress and strain rate, responsible for the tectonic deformation of those process remain poorly understood (Engelder, 1993; Ranalli, 1995). In the case of tectonically active regions, the magnitude of differential stress can be estimated using geophysical data or measured directly in the uppermost part of the lithosphere (e.g. Molnar \& England, 1990; Whitmarsh et al., 1991). Alternatively, the magnitude of differential stress in the exhumed orogenic belts inaccessible to direct measurement can be derived from the microstructures in ductile deformed rocks (e.g. Goetze \& Kohlstedt, 1973, Twiss, 1977; Koch 1983; Gleason \& Tullis, 1993). Consequently, the estimated flow stress values can be used, in conjunction with the temperature history of the rocks and experimentally flow laws, to infer the strain rate during the development of ductile shear zones (e.g. Paterson \& Luan, 1990; Gleason \& Tullis, 1993).

The aim of this paper is to use theoretically derived microstructural piezometry of quartz to infer the differential stress during the deformation of quartzose rocks of the Phyllite-Quartzite Series (PQS) in the Peloponnese. The strain rate and effective viscosity during the syn-compressional exhumation of these rocks are then estimated by applying quartzite flow laws at the calculated stresses and published metamorphic temperatures. For the purpose of this analysis 36 representative quartz-rich samples were selected from the PQS, which derived from the cores of two major tectonic windows (Chelmos, Taygetos, Fig. 1a).

\section{TECTONIC SETTING}

The Peloponnese comprises a nappe pile of different tectonic units (Fig. 1), each characteristic of a distinct paleogeographic domain in the External Hellenides. From top to bottom, and from internal to external in terms of paleogeographic configuration within the Apulian, four main tectono-stratigraphic units can be distinguished (e.g. Jacobshagen 1986): (1) The «Pindos Thrust Belt» which comprises mainly deep-water carbonates, and siliclastic and siliceous Mesozoic-Cenozoic rocks; (2) the «Tripolitza-Tyros Zone» which represents mainly a thick carbonate platform of Mesozoic-Cenozoic age; (3) the metamorphic sequence of the «Phyllite-Quartzite Series» (PQS) which is considered as an original Permo-Triassic volcanic-clastic rift sequence; and (4) the metamorphic Mesozoic-Cenozoic «Plattenkalk Series» which is either part of the Ionian or the Pre-Apulian zone.

1. University of Patras, Department of Geology, 26500, Patras, Greece, Email address: P.Xypolias@upatras.gr 


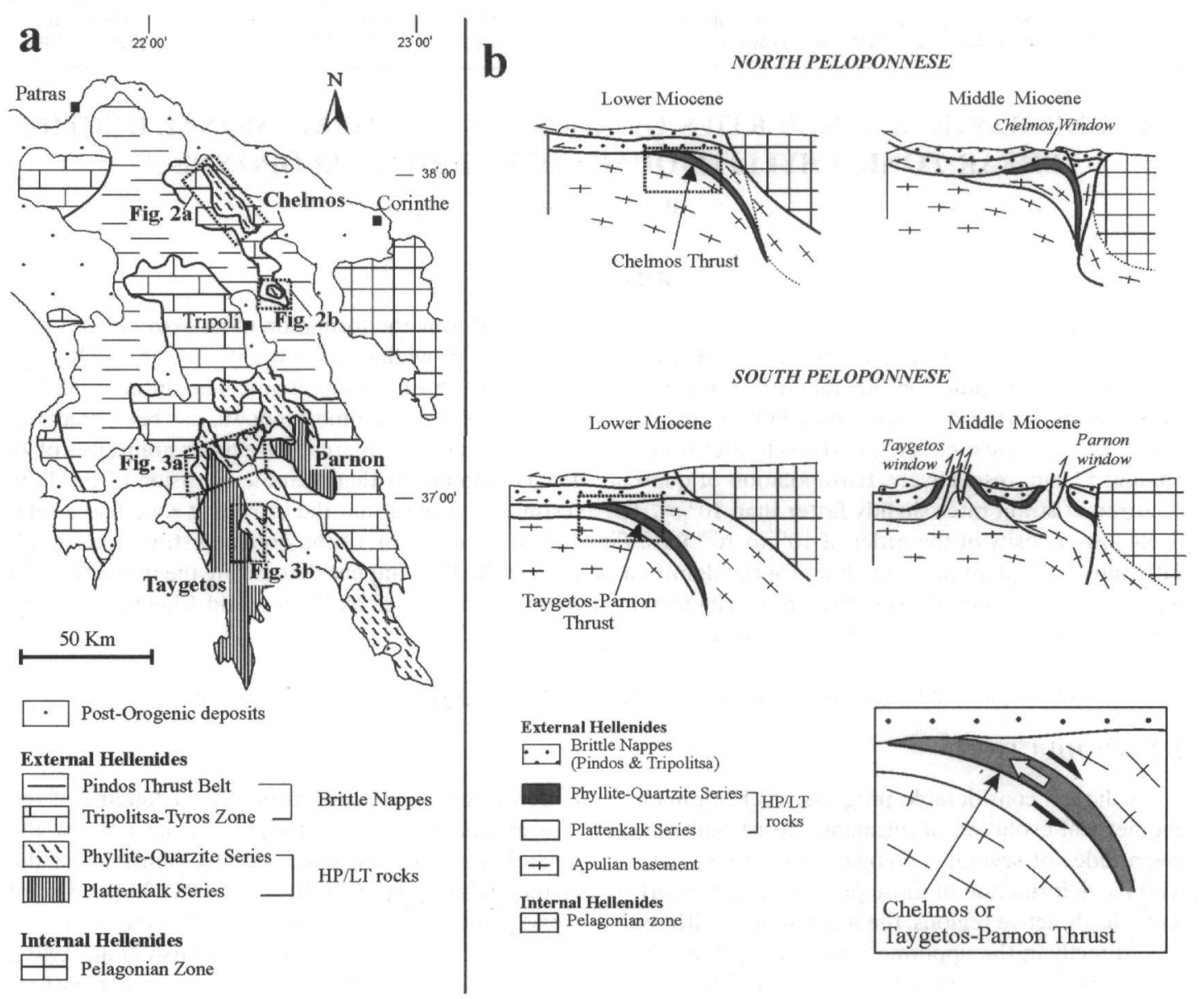

Figure 1. (a) General tectonic map of the Peloponnese, showing principal structural units and the location of the Chelmos and Taygetos windows. The locations of the maps in Figures $2 a, 2 b, 3 a$ and $3 c$ are indicated by boxes. (b) Evolutionary models of the development of the north (by Xypolias \& Doutsos, 2000) and south Peloponnese (by Doutsos et al., 2000) along east-west geological cross-sections. Inset shows in detail the solid-state extrusion of the Phyllite-Quartzite Series.

The External Hellenides in the Peloponnese developed during Tertiary time, following the closure of Pindos Ocean and the consequent continent - continent collision between the Apulian and Pelagonian. In the course of this tectonism, the protolith of the PQS, which was underthrust beneath the Tripolitsa basement (e.g. Thiebault \& Triboulet, 1984), underwent metamorphism resulting in the formation of greenschist to blueschist metamorphic assemblages (e.g. Katagas, 1980). This middle to high-pressure event is geochronologically dated at $c a 23$ $\mathrm{Ma}$ (Seidel et al. 1982). In the South Peloponnese, peak metamorphic conditions for the PQS have been estimated at $400 \pm 50^{\circ} \mathrm{C}$ and $11-13 \mathrm{kbar}$ by Theye (1988) or $450^{\circ} \pm 30^{\circ} \mathrm{C}$ and $17 \pm 4 \mathrm{kbar}$ by Theye \& Seidel (1991). According to Bassias \& Triboulet (1993), in the Taygetos area the maximum conditions of this metamorphism reached temperatures of $400^{\circ} \mathrm{C}$ and pressures of $10 \mathrm{kbar}$. P-T conditions during metamorphism of the rocks exposed in the Chelmos window (PQS) are estimated at $375^{\circ} \pm 25^{\circ} \mathrm{C}$ and $5 \mathrm{kbar}$ (e.g. Katagas et al., 1991). The exhumation history of the PQS began at the Oligocene-Miocene boundary. At this time, the PQS acted as a ductile shear zone and started to extrude westwards between the «Taygetos-Parnon Thrust», or the «Chelmos Thrust» (see Fig. 1b), and the basement of Tripolitsa-Tyros Zone (Xypolias \& Doutsos, 2000; Doutsos et al., 2000). The final effect of this extrusion process was to place the metamorphosed rocks of the PQS in contact with the overlying unmetamorphosed cover nappes along a normal fault (Fig. 1b), but in a tectonic setting without any net extension of the overall system. 


\section{MICROSTRUCTURES IN THE PQS}

Ductile deformation within the PQS produced a penetrative foliation and a well-developed ENE-WSW trending mineral-stretching lineation (Figs. 2,3) which is defined by streaks of white mica, actinolite and elongated quartz aggregates. Quartz-rich tectonites have undergone extensive dynamic recrystallization and formed well-developed lattice and grain shape preferred orientation patterns, indicating dislocation creep as the dominant mechanism. Shear sense indicators, such as microstructures (oblique grain shape in recrystallized quartzites, mica-fish) and quartz c-axis fabrics, indicate that crystal-plastic deformation within the PQS was associated with top-to-the W-SW sense of shearing (Xypolias \& Doutsos, 2000; Doutsos et al. 2000). Samples analysed for this study, from both the Chelmos and Taygetos areas (Figs 1,2,3), are composed of quartz as the main constituent with phyllosilicates (white mica and/or chlorite) varying from 5 to 30 modal percent. Microscopic analysis in these samples showed that the dynamic recrystallization of quartz aggregates is controlled by a combination of both progressive subgrain-rotation (SR) and grain-boundary-migration (GBM) recrystallization. Microstructures indicative of SR-recrystallization, such as core-and-mantle structures (White, 1976); and microstructures indicative of GBM-recrystallization, such as grain-boundary-bulging (White, 1976), castellate microstructures, window and dragging microstructures (Jessel, 1987), are observed in the analysed samples, either individually or in combination with the same sample. Summarising, microstructures indicating a coupling of progressive SRand GBM- recrystallization, specimens having extensive dynamic recrystallization and the present of oblique grain shape in quartoze rocks (see above) may be interpreted as a result of deformation in the dislocation creep regime III or in a transitional dislocation creep regime II and III (Hirth \& Tullis, 1992).

\section{RECRYSTALLIZED GRAIN SIZE PIEZOMETRY}

The differential flow stress in dislocation creep is related to certain microstructural parameters such as recrystallized grain size, sub-grain size and dislocation density. This raises the possibility that the palaeostress of rocks can be estimated from these parameters. In this work, theoretically derived and experimentally calibrated grain-size piezometry of quartz was used to infer the differential flow stress of deforming aggregates assuming steady state dislocation creep. The recrystallized grain size from the 36 selected quartz-rich samples (19 from the Chelmos area and 17 from the Taygetos area, Figs. 2,3) was determined using the Heyn method of linear intercept analysis (see DeHoff \& Rheins, 1968). About 500-800 grains were measured in each thin section and the grain size was calculated from the relationship $1.5(\mathrm{abc})^{1 / 3}$, where $\mathrm{a}, \mathrm{b}$ and $\mathrm{c}$ are the number of grains per unit length on three different traverses across the thin section. Three traverses were chose parallel, perpendicular and at $45^{\circ}$ to the microscopic foliation. Only pure quartz layers were measured, because impurities (e.g. mica) hinder grain-boundary migration and generally produce a smaller stable grain size (Christie and Ord, 1980). To evaluate flow stress, the recrystallized grain size piezometer derived by Twiss (1977) was used, as it is a piezometer most closely matching the newly established laws for quartz aggregates (Gleason and Tullis, 1993). It follows the form:

$$
\sigma=\mathrm{A} \cdot D^{-\mathrm{m}}
$$

where $\sigma$ is the differential stress $\left(\sigma_{l}-\sigma_{3}\right), D$ is the grain size in $\mathrm{mm}$, and A $(=603 \mathrm{MPa})$ and $\mathrm{m}(=0.68)$ are constants (Twiss, 1977).

\subsection{RESULTS}

The results of recrystallized quartz grain size measurements from 36 samples are given in Figure 4a. Recrystallized grain sizes of all 19 samples from the Chelmos area span the range 30-109 mm (Fig. 4a). However, the values of the grain size obtained can be separated into two major groups. As displayed schematically in Figure 4b, the grain sizes (D) from 13 samples (Group A) are tightly clustered between 30 and $52 \mathrm{~mm}$ while in the rest 6 samples (Group B) the values of parameters D appears to be higher and lie in the range of 77-109 mm. Furthermore, it is significant to say that the 13 samples of group A were selected within the lower, more intensely recrystallized levels of the PQS. In contrast, the six samples (FN1, FN2, FN4, FN16, AG1, AG10) of the group B are restricted within a narrow zone close to the contact between the PQS with the Tyros Beds and/or Tripolitza Zone (see Fig. 2). This observation suggests that the samples of group A are more representative and describe more effectively the distribution of the grain size in the PQS than the samples of the group B. The average grain size for group $A$ is of the order of $42 \mathrm{~mm}$. The 17 samples collected from the Taygetos area contain recrystallized quartz grains with a more restricted range of size from 32 to $67 \mathrm{~mm}$; twelve out of 17 are within the range $41-59 \mathrm{~mm}$ (Fig. 4c). The average grain size for the Taygetos area's samples is of the order of $51 \mathrm{~mm}$. 


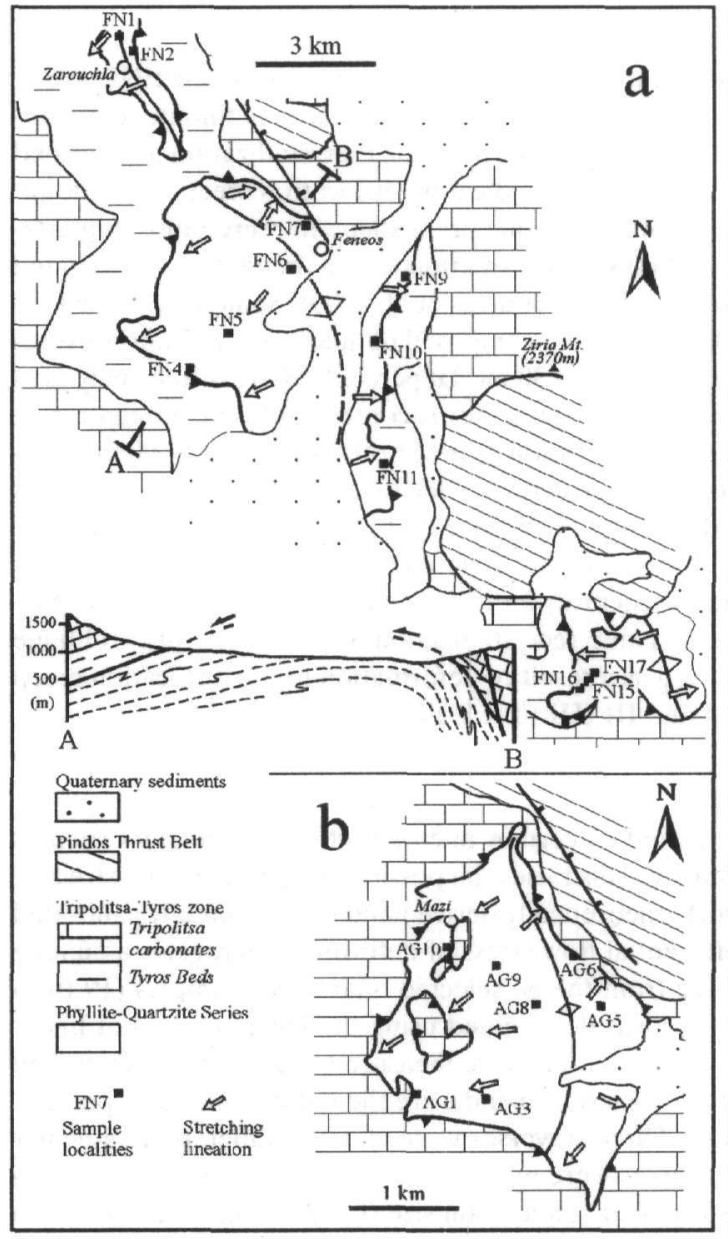

Figure 2. Structural and sample maps for the northern (a) and southern (b) part of the Chelmos window. For the location of the maps see Figure 1.

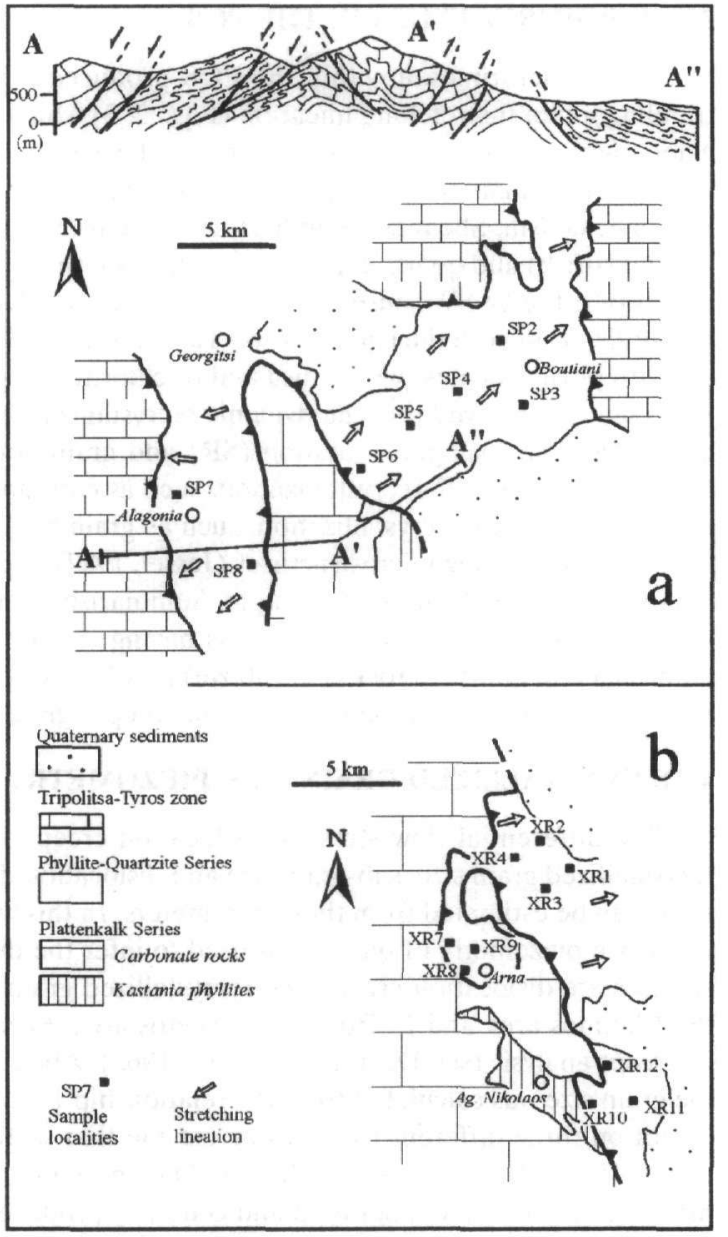

Figure 3. Structural and sample maps for the northern (a) and southern (b) part of the Taygetos window. For the location of the maps see Figure 1.

Based on Twiss calibration, the differential flow stresses implied for the average recrystallized grain sizes 42 $\mathrm{mm}$ from the Chelmos area and the $51 \mathrm{~mm}$ from the Taygetos area are of the order of $47 \mathrm{MPa}$ and $41 \mathrm{MPa}$, respectively.

\section{ESTIMATE OF STRAIN RATE}

Differential flow stresses estimations can be combined with metamorphic temperature estimates to calculate the strain rate during deformation, by using published flow-laws. Flow-laws are derived from laboratory experiments and in some cases it may be justified to extrapolate them to geological conditions. In this work, the flow law for dislocation creep of quartz derived by Paterson and Luan (1990) for low to moderate grade rocks was applied. It has the form:

$$
e=A \sigma^{n} \exp (-Q / R T),
$$

with $A$ (pre-exponential factor) $=6.5 \times 10^{-8} \mathrm{MPa}^{-\mathrm{n}} \mathrm{s}^{-1}, Q$ (activation energy) $=135 \mathrm{kJmol}^{-1}, R$ (gas constant) $=8.314 \mathrm{JK}^{-1} \mathrm{~mol}^{-1}$ and $n$ (stress exponent) $=3.1 ; e$ denote the strain rate, $\mathrm{s}$ the differential stress and $T$ the absolute temperature. As it has been noted in previous sections, the peak metamorphic temperatures for the PQS in the Chelmos window have been estimated at $375 \pm 25^{\circ} \mathrm{C}$ (Katagas et al., 1991) while for the same rock unit in the Taygetos window at $400^{\circ} \mathrm{C}$ (Bassias \& Triboulet, 1993). Finally, using the above flow-law, for temperatures 


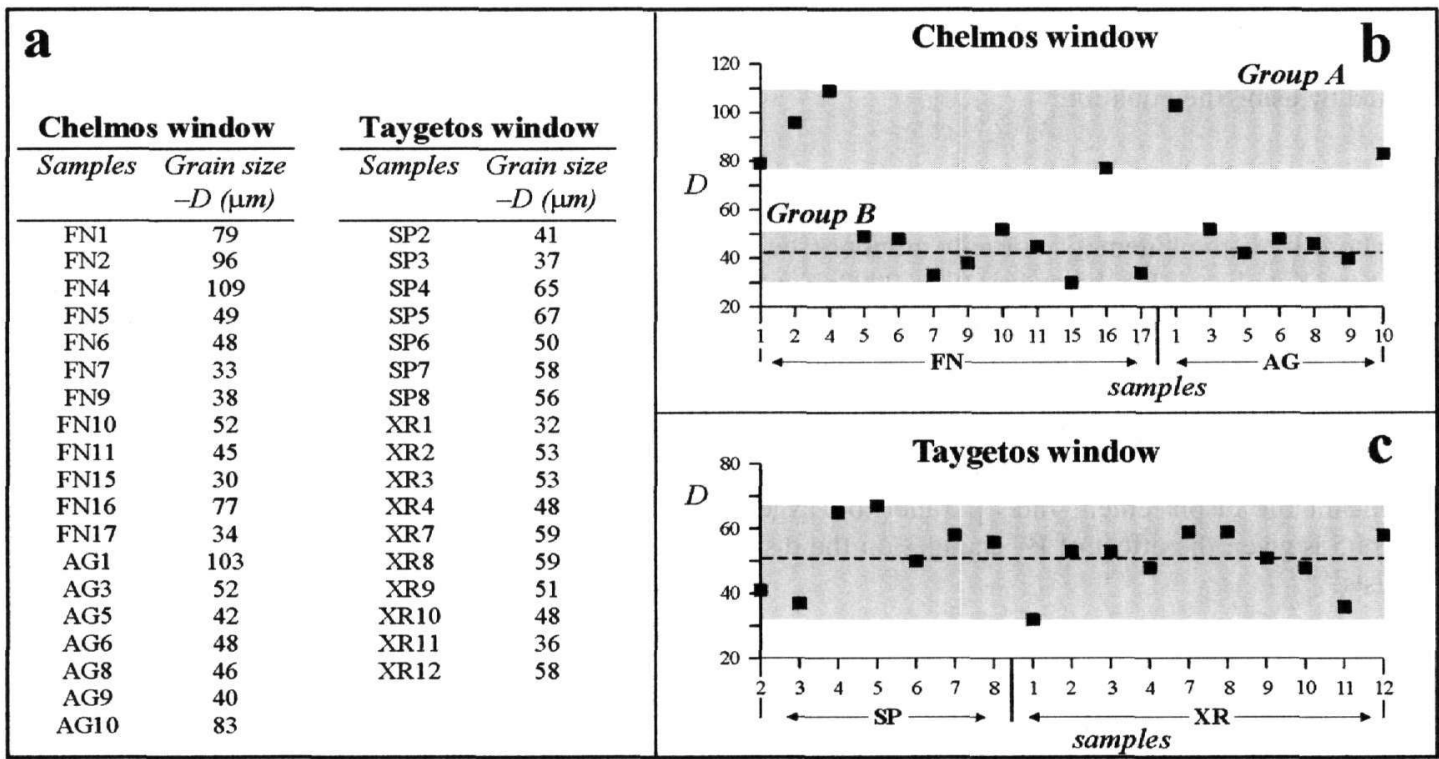

Figure 4. (a) The recrystallized quartz grain size from 36 samples. For sample localities see Figures 2 and 3. (b) Plot illustrating the variations of grain size (D) values vs. samples from the Chelmos window. The shaded areas show the value's ranges for two major groups and the dashed line indicates the average grain size. (c) Plot illustrating the variations of grain size (D) values $v s$. samples from the Taygetos window. The shaded area shows the value's range and the dashed line indicate the average grain size.

$375^{\circ} \mathrm{C}$ and differential stress $47 \mathrm{MPa}$, a strain rate of $10^{-13} \mathrm{~s}^{-1}$ (or $3.15 \mathrm{Ma}^{-1}$ ) is calculated for the samples from the Chelmos area. At temperatures $400^{\circ} \mathrm{C}$ and differential stress $41 \mathrm{MPa}$, the predicted strain rate for the rocks from the Taygetos area is of the order of $2.1 \times 10^{-13} \mathrm{~s}^{-1}$ ( or $6.61 \mathrm{Ma}^{-1}$ ). It should be noted that the observed strain rate values from both areas, lie in the limit of the conventional strain rates range $\left(10^{-13} \mathrm{~s}^{-1}-10^{-15} \mathrm{~s}^{-1}\right)$ suggested by Pfiffner \& Ramsay (1982). According to the above authors, strain rates faster than $10^{-13} \mathrm{~s}^{-1}$ have been expected in mylonite zones.

\section{ESTIMATE OF EFFECTIVE VISCOSITY}

Estimations of the effective viscosity (h) during ductile deformation of the PQS can be made combining flow stress and strain rate data according to the following relation:

$$
\eta=\sigma / 3(d e / d t)
$$

(e.g. Carter \& Tsenn, 1987). From the formula it is obvious that derivation of a good estimate of viscosity can be made only if deformation is homogeneous and continuous in time $(t)$. Therefore, a conservative estimation can be given assuming constant strain rate and continuous deformation over a time span of $1 \mathrm{Ma}$. Consequently, using the observed differential stresses and strain rates values, an effective bulk viscosity for the rocks of the PQS in both windows in the range $10^{20}$ to $10^{19} \mathrm{~Pa} \cdot \mathrm{s}$ is inferred.

\section{IMPLICATION FOR THE DISPLACEMENT RATE}

Calculations of the displacement rates parallel $\left(V_{P}\right)$ to the Taygetos-Parnon and Chelmos Thrust (Fig. 1), during the tectonic extrusion of the PQS, appears to be possibly if the thickness $(h)$ of the ductile shear zone and shear strain rate $\left(e_{s}\right)$ are known:

$$
V_{P}=e_{S} \cdot h
$$

(e.g. Jiang 1994). Field observations and published geological cross-section from the Peloponnese (e.g. A- 
A-A"' in Fig. 3a) and Crete (Kokkalas \& Doutsos, 2000) indicate that the PQS has a relatively fixed structural thickness approximately $1000 \mathrm{~m}$. According to Weijermars (1998) calculations of shear strain rate can be performed by using the equation:

$$
e_{S}=e \cdot W_{k} \text {, }
$$

where $W_{k}$ is the kinematic vorticity number (see Means, 1994 for review). Considering, recent quantitative analyses (Xypolias \& Koukouvelas, 1999, 2000; Xypolias \& Doutsos, 2000) showed that ductile deformation of the rocks in the PQS has started with an initially high $W_{k}\left(W_{k} \approx 0.9\right)$ which reduced as deformation proceeded $\left(0.6<W_{k}<0.4\right)$. Finally, for $e$ of $6.61 \mathrm{Ma}^{-1}, W_{k}$ of 0.9 and $h$ of $1000 \mathrm{~m}$, a displacement rate $5.9 \mathrm{~mm} / \mathrm{year}$ (or $5.9 \mathrm{~km} /$ Ma) parallel to the Taygetos-Parnon Thrust, during the initial stages of extrusion process, is obtained. For $e$ of $3.14 \mathrm{Ma}^{-1}, W_{k}$ of 0.9 and $h$ of $1000 \mathrm{~m}$ the displacement rate parallel to the Chelmos Thrust is $2.8 \mathrm{~mm} /$ year (or 2.8 $\mathrm{km} / \mathrm{Ma}$ ). However, it is obvious that the progressive decrease of $W_{k}$ during ductile deformation was affected significant the displacement rates parallel to Taygetos-Parnon and Chelmos Thrusts. In the diagram of the Figure 5 is given the effect of $W_{k}$ changes on the displacement rates parallel to Taygetos-Parnon and Chelmos Thrusts.

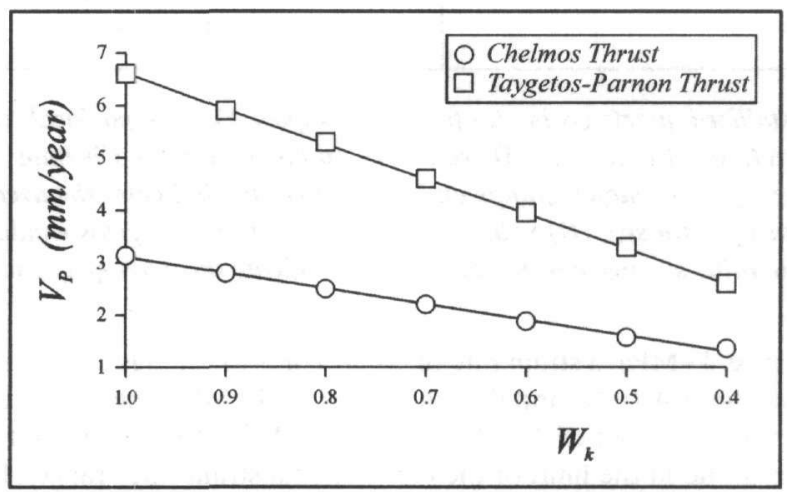

Figure 5. Diagram showing the effect of $\mathrm{W}_{\mathrm{k}}$ (kinematic vorticity number) changes on the displace-ment rates (Vp) parallel to Chelmos and Taygetos - Parnon Thrusts. The ductile extrusion of the Phyllite - Quartzite Series propably starts with an initially high $\mathrm{W}_{\mathrm{k}}$ value which reduces as deformation proceeds.

\section{CONCLUDING REMARKS}

Quartzites from the Phyllite-Quartzite Series (PQS) in the Chelmos and Taygetos tectonic windows (Peloponnese) have average recrystallized grain sizes of $42 \mathrm{~mm}$ and $51 \mathrm{~mm}$, respectively. Twiss's (1977) quartz grainsize piezometer suggests that the ductile deformation occurred at differential stresses approximately 40-50 MPa. Extrapolation of quartzite flow-laws indicates that the ductile deformation in the PQS occurred at strain rates slightly faster than $10^{-13} \mathrm{~s}^{-1}$. These stress and strain rate estimates suggest that during tectonic extrusion of the $\mathrm{PQS}$, rocks had a relatively low-viscosity in the range $10^{20}$ to $10^{19} \mathrm{~Pa} \cdot \mathrm{s}$. Combination of the obtained strain rate values with published quantitative analyses of the rotational and stretch components of deformation indicates that during the initial stage of the tectonic extrusion process, the displacement rates parallel to the TaygetosParnon and Chelmos Thrusts were $\sim 6 \mathrm{~mm} /$ year and $3 \mathrm{~mm} / \mathrm{year}$, respectively.

\section{ACKNOWLEDGMENTS}

The author is grateful to Prof. N. Fytrolakis and Dr. Z. karotsieris for critical reading on an earlier version of the manuscript. 


\section{REFERENCES}

BASSIAS, Y. \& TRIBOULET, C. 1993. Tectono-Metamorphic evolution of Blueschist formations in the Peloponnesus (Parnon and Taygetos Massifs, Greece): A model of nappe stacking during Tertiary Orogenesis. Journal of Geology 102, 697-708.

CARTER, N. L. \& TSENN, M. C. 1987. Flow properties of continental lithosphere. Tectonophysics 136, $27-63$.

CHRISTIE, J. M. \& ORD, A. 1980. Flow stress from microstructures of mylonites: example and current assessment. Journal of Geophysical Research 85, 6253-6262.

DEHOFF, R. T. \& RHEINS, F. N. 1968. Quantitative Microscopy, 422pp. (McGraw-Hill, New-York).

DOUTSOS, T., KOUKOUVELAS, I., POULIMENOS, G., KOKKALAS, S., XYPOLIAS, P. \& SKOURLIS, K. 2000. An exhumation model of the south Peloponnesus, Greece. International Journal of Earth Sciences 89 , 350-365.

ENGELDER, T. 1993. Stress Regimes in the Lithosphere, 457pp. (Princeton University Press, Pricenton).

GLEASON, G. C. \& TULLIS, J. 1993. Improving flow laws and piezometers for quartz and feldspar aggregates. Geophysical Research Letters 20, 2111-2114.

GOETZE, C. \& KOHLSTEDT, D. L. 1973. Laboratory studies of dislocation climb and diffusion in olivine. Journal of Geophysical Research 78, 5961-5976.

HIRTH, G. \& TULLIS, J. 1992. Dislocation creep regimes in quartz aggregates. Journal of Structural Geology 14, 145-159.

JACOBSHAGEN, V. 1986. Geologie von Griechenland. 363 pp. (Gebruder Borntraeger, Berlin).

JESSELL, M. W. 1987. Grain-boundary migration microstructures in a natural deformed quartzite. Journal of Structural Geology 9, 1007-1014.

JIANG, D. 1994. Flow variation in layered rocks subjected to bulk flow of various kinematic vorticities: theory and geological implications Journal of Structural Geology 16, 1159-1172.

KATAGAS, C. 1980. Ferroglaucophan and chloritoid-bearing metapelites from the phyllite series, southem Peloponnese Greece. Mineralogical Magazine 43, 975-978.

KATAGAS, C., TSOLIS-KATAGAS, P. \& BALTATZIS, E. 1991. Chemical mineralogy and illite crystallinity in low grade metasediments, Zarouchla Group, Northern Peloponnesus, Greece. Mineralogy and Petrology 44, 57-71.

KOCH, P.S. 1983. Rheology and microstructures of experimentally deformed quartz aggregates. Unpublished $\mathrm{PhD}$ thesis, University of California.

KOKKALAS, S. \& DOUTSOS, T. 2000. Strain partitioning along the south Hellenides (Eastern Crete, Greece). In: Panayides, I., Xenophontos, C., Malpas, J. (Eds.), Third International Conference on the Geology of the Eastern Mediterranean. Department of Geological Survey, Nicosia, Cyprus, 83-95.

MEANS, W. D. 1994. Rotational quantities in homogeneous flow and the development of small-scale structure. Journal of Structural Geology 16, 437-445.

MOLNAR, P. \& ENGLAND, P. 1990. Temperatures, heat flux, and frictional stress near major thrust faults. Journal of Geophysical Research 95, 4833-4856.

PATERSON, M. S., LUAN, F. C. 1990. Quartzite rheology under geological conditions. In: Knipe, R.J., Rutter, E.H. (Eds.), Deformation Mechanisms, Rheology and Tectonics. Geological Society of London Special Publication. 54, pp. 299-307.

PFIFFNER, O. A. \& RAMSAY, J. G. 1982. Constraints on geological strain rates-arguments from finite strain states of naturally deformed rocks. Journal of Geophysical Research 87, 311-321.

RANALLI, G. 1995. Rheology of the Earth. 388pp. (Chapman \& Hall, London).

SEIDEL, E., KREUZER, H. \& HARRE, W. 1982. A late Oligocene/early Miocene high pressure belt in the external Hellenides. Geologische Jarhbuch E23, 165-206.

THEYE, T. 1988. Aufsteigende Hochdruckmetamorphose in Sedimenten der Phyllit-Quarzit-Einheit Kretas und des Peloponnes. Unpublished PhD thesis, University of Braunschweig.

THEYE, T. \& SEIDEL, E. 1991 Petrology of low-grade high pressure metapelites from the External Hellenides (Crete Peloponnese) A case study with attention to sodic minerals. European Journal of Mineralogy 3, 343366.

THIEBAULT, F. \& TRIBOULET, T. 1984. Alpine metamorphism and deformation in Phyllite nappes (external Hellenides, southern Peloponnesus, Greece): Geodynamic implication. Journal of Geology 92, 185-199.

TWISS, R.J., 1977. Theory and applicability of a recrystallized grain-size paleopiezometer. Pure and Applied Geophysics 115, 227-244. 
WEIJERMARS, R. 1998. Principles of Rock Mechanics. 359pp. (Alboran Science, Amsterdam).

WHITE, S., 1976. The effect of strain on the microstructures, fabrics and deformation mechanisms in quartzites. Philosophical Transactions of the Royal Society of London A283, 69-86.

WHITMARSH, R. B., BOTT, M. H. P., FAIRHEAD, J. D. \& KUSZNIR, N. J. 1991. Tectonic stress in the lithosphere, 194pp. (Philosophical Transactions of the Royal Society of London A337).

XYPOLIAS, P. \& DOUTSOS, T. 2000. Kinematics of rock flow in a crustal-scale shear zone: implication for the orogenic evolution of the southwestern Hellenides. Geological Magazine 137, 81-96.

XYPOLIAS, P. \& KOUKOUVELAS, I. 1999. Flow-path partitioning in the Chelmos monoclinic shear zone, Peloponnese, Greece. Tubinger Geowissenschaftliche Arbeiten A52, 217-218.

XYPOLIAS, P. \& KOUKOUVELAS, I. 2000. Kinematic vorticity and strain rate patterns associated with ductile extrusion in the Chelmos Shear Zone (External Hellenides, Greece). Tectonophysics, (in press). 